\title{
Identification of differentially expressed genes in parasitic phase Miamiensis avidus (Ciliophora: Scuticociliatia) using suppression subtractive hybridization
}

\author{
Eun Hye Lee, Ki Hong Kim* \\ Department of Aquatic Life Medicine, Pukyong National University, Busan 608-737, South Korea
}

\begin{abstract}
Miamiensis avidus, a causative agent of scuticociliatosis in cultured marine fish, can live not only in seawater as a free-living organism but also in fish as a parasite. In this study, a cDNA library of representative mRNAs more specific to parasitic phase $M$. avidus was generated using suppression subtractive hybridization (SSH), and 520 clones selected from the SSH library were singlerun sequenced. The differential gene expression patterns were confirmed by semi-quantitative reverse-transcription PCR. Of the 510 SSH clones, 21 clones of 6 putative genes did not match sequences in the public database. The expectation values ( $E$-values) of 117 clones encoding 9 putative genes were greater than $1 \times 10^{-5}$. The other 372 clones that met the criterion of $E$ value $<1 \times 10^{-5}$ were matched to 26 known sequences in the database. Genes associated with signal transduction, cell proliferation, membrane transportation, protein translocation, and transcription regulation were preferentially expressed in parasitic phase $M$. avidus. The differential gene expression may be needed for the ciliates to survive in the host fish, and the corresponding proteins might be used as antigen candidates for development of scuticociliatosis vaccines.
\end{abstract}

KEY WORDS: Miamiensis avidus - Cultured - Parasitic phase ciliates - Suppression subtractive hybridization · Antigen candidates

\section{INTRODUCTION}

The facultative parasitic ciliate Miamiensis avidus, which is the synonym of Philasterides dicentrarchi reported by Kim et al. (2004) (Jung et al. 2007, Song et al. 2009), is a causative agent of scuticociliatosis, and leads to high cumulative mortalities in cultured olive flounder Paralichthys olivaceus in Korea (Kim et al. 2004, Jung et al. 2007). As there are, at present, no effective in vivo chemotherapeutants, especially for systemic infections, effective vaccines against scuticociliatosis would be highly desirable.

The external surface of ciliates is mainly covered with a glycosylphosphatidyl inositol (GPI) anchored glycoprotein called surface antigen, also called immobilization antigens (i-antigens). The i-antigens have been intensively studied as the principal target antigen for vaccine development against Ichthyophthirius multifiliis, an obligate parasitic ciliate of freshwater fish (Clark et al. 1995, Wang \& Dickerson 2002). However, because of the existence of several serotypes in $I$. multifiliis, i-antigen-mediated immunity is serotype-specific (Dickerson et al. 1993, Dickerson \& Clark 1996, 1998, Wang et al. 2002). Generally, freeliving ciliates have several different i-antigens, which are alternatively expressed according to ambient environment changes (Caron \& Meyer 1989, Simon \& Schmidt 2007). Since Miamiensis avidus can live not only in seawater as a free-living organism but also in fish as a parasite, the ciliates should experience harsh environmental changes during penetration of fish tissue. Recently, we have demonstrated that sera 
of olive flounder immunized with in vitro cultured $M$. avidus showed agglutination activity to the cultured ciliates but not to the parasitic-phase ciliates, even though originating from the same cultured ciliate population (Lee \& Kim 2008). Moreover, it has been observed that agglutinated scuticociliates following exposure to immune sera escaped from the agglutinated mass within a few hours and displayed no adverse effects (Iglesias et al. 2003, Lee \& Kim 2008). Therefore, we suggest that other surface antigens expressed constitutively or expressed specifically under the infection state (needed for survival of the ciliates in the host fish) might be more suitable to develop protective subunit vaccines against scuticociliatosis (Lee \& Kim 2008).

It is reasonable to assume that survival and disease establishment of Miamiensis avidus in fish host are closely associated with a set of genes expressed specifically in the parasitic phase. However, no information on $M$. avidus genes related to parasitic phase has so far appeared in the literature. The aim of the present study is to find ciliate genes differentially expressed by $M$. avidus in the infectious state using suppression subtractive hybridization ( $\mathrm{SSH}$ ), and discuss the potential of those up-regulated genes as antigen candidates for development of subunit vaccine against scuticociliatosis.

\section{MATERIALS AND METHODS}

Ciliates. Ciliates were isolated from ascitic fluid of an infected olive flounder Paralichthys olivaceus collected from a local fish farm in Korea and were identified as Miamiensis avidus (syn. Philasterides dicentrarchi) using species-specific oligonucleotide primers (Kim et al. 2004). Chinook salmon embryo (CHSE)214 cells, incubated at $20^{\circ} \mathrm{C}$ in Eagle's minimum essential medium (MEM; Sigma) supplemented with $10 \%$ heat-inactivated fetal bovine serum, were used as grazing material to grow the ciliates in axenic culture condition.

To obtain parasitic phase ciliates belonging to the same population of the above cultured ciliates, $1 \times 10^{5}$ cells of the CHSE-cultured ciliates were injected into intraperitoneal cavity of juvenile olive flounder weighing 10 to $15 \mathrm{~g}$. After 3 to $5 \mathrm{~d}$ following injection, the parasitic-phase ciliates were isolated from ascitic fluid of the fish (showing severe abdominal expansion) using a syringe, and incubated for $1 \mathrm{~h}$ at $20^{\circ} \mathrm{C}$ to let the ciliates graze contaminating fish cells present in the ascitic fluid. The ciliates were then harvested by centrifugation at $200 \times g$ for $5 \mathrm{~min}$, and washed 3 times by centrifugation at $150 \times g$ for $5 \mathrm{~min}$ in $10 \mathrm{ml}$ of Hanks' balanced salt solution (Sigma).
RNA preparation. Total RNA from ciliates harvested from CHSE culture or from artificially infected flounder was prepared using RNAiso (Takara) according to the manufacturer's instructions. Poly $\mathrm{A}^{+}$RNA from the total RNA was isolated using PolyATract mRNA isolation system IV (Promega). After total and poly $\mathrm{A}^{+} \mathrm{RNA}$ isolation, RNA's integrity was determined by ultraviolet (UV) spectrophotometry (Ultrospec ${ }^{\circledR} 3100$ pro, Amersham Phamacia Biotech) and formaldehyde gel electrophoresis.

SSH. SSH was performed using the PCR-Select ${ }^{\mathrm{TM}}$ cDNA Subtraction Kit (Clontech) according to the manufacturer's instructions. Briefly, $2 \mu \mathrm{g}$ of poly $\mathrm{A}^{+}$ RNA from both parasitic-phase and CHSE-cultured Miamiensis avidus were reverse transcribed into single-stranded cDNA in a reaction containing $1 \mu \mathrm{M}$ cDNA synthesis primer, $1 \times$ first-strand buffer, $1 \mathrm{mM}$ dNTP, and 20 units AMV reverse transcriptase. The second-strand cDNAs were synthesized using secondstrand enzyme cocktail containing DNA polymerase I, RNase H, and Escherichia coli DNA ligase. The bluntending of DNA ends was performed by T4 DNA polymerase. The cDNAs were then phenol-extracted, ethanol-precipitated, and digested by 15 units of RsaI restriction enzyme to generate shorter, blunt-ended, double-stranded cDNA fragments, which are optimal for subtraction and required for adaptor ligation. The RsaI-digested cDNA of parasitic phase ciliates (tester cDNA) was separated into 2 pools that were ligated to different adaptors (adaptor 1 and adaptor 2R). The RsaI-digested cDNA $(1.5 \mu \mathrm{l})$ of the CHSE-cultured ciliates (driver cDNA) and $4 \times$ hybridization buffer $(1 \mu \mathrm{l})$ were added to each of 2 seperate tubes containing $1.5 \mu \mathrm{l}$ of adaptor 1- and 2R-ligated RsaI-digested cDNA of parasitic phase ciliates (tester cDNA). The samples were denatured at $98^{\circ} \mathrm{C}$ for $1.5 \mathrm{~min}$ after overlaying with one drop of mineral oil, and then allowed to hybridize at $68^{\circ} \mathrm{C}$ for $8 \mathrm{~h}$ in a thermal cycler. After this first hybridization, the 2 samples were combined, and $1 \mu \mathrm{l}$ of freshly heat-denatured driver cDNA (cDNA of the CHSE-cultured ciliates) was added, and then the sample was allowed to hybridize at $68^{\circ} \mathrm{C}$ overnight in a thermal cycler. After 2-step hybridization of adaptor-ligated tester cDNA and an excess of driver cDNA as above, the parasitic phase $M$. avidus specific, double-stranded cDNA with both adaptors was generated. To amplify this parasitic phase $M$. avidus-specific, ds cDNA with both adaptors, 2 rounds of PCR were performed with primers specific for the adaptor sequence. The reverse subtraction was performed simultaneously following the above protocol. In the reverse subtraction, the cDNA of CHSE-cultured ciliates was used as a tester and the cDNA of parasitic phase ciliates was used as a driver. Aliquots from the primary and secondary PCR reac- 
tion were analyzed by $2 \%$ agarose gel electrophoresis. And the secondary PCR products were diluted and applied to an additional PCR reaction to evaluate the subtraction efficiency using a primer set specific for $\beta$-tubulin gene (GenBank accession number GQ342956.1) of $M$. avidus. The nucleotide sequences of $\beta$-tubulin gene-specific primers are shown in Table 1. PCR was performed on the forward-subtracted cDNA, unsubtracted tester control cDNA for the forward subtraction reaction, reverse-subtracted cDNA, and unsubtracted tester control cDNA for the reverse subtraction reaction, respectively.

Cloning and sequence analysis. For the forwardsubtracted cDNA, the final PCR products from the SSH procedure was ligated with $\mathrm{pGEM}-\mathrm{T}$ easy vector (Promega) and transformed into Escherichia coli DH5 $\alpha$. E. coli colonies containing the plasmid vectors with inserted PCR products were selected by spreading the transformants onto a Luria-Bertani (LB) agar plate containing ampicillin, 5-bromo-4-chloro-3-
indolyl-D-galactoside (X-Gal), and isopropyl 1-thio- $\beta$ D-galactopyranoside (IPTG). Plasmid DNA were isolated from overnight culture of the randomly picked individual white colonies using GeneALL Plasmid miniprep kit (General Biosystem) according to the manufacturer's instruction. DNA sequencing was performed using automatic sequencer ABI3730xl (96capillary, Applied Biosystems) according to the protocol of ABI Prism ${ }^{\circledR}$ BigDye $^{\mathrm{TM}}$ Terminator Cycle Sequencing Ready Reaction Kits version 3.1 at the Macrogen. To identify a putative set of genes expressed in infection state of Miamiensis avidus, 520 clones isolated from the SSH library were singlerun sequenced. After removing the vector sequence and eliminating clones with a poor sequence quality, nucleotide sequences of the remaining 510 clones were compared to previously reported sequences in the EMBL/GenBank databases using the BLASTX search analysis algorithm of National Center for Biotechnology Information (NCBI).

Table 1. Primer sequences and conditions used in the semi-quantitative reverse-transcription PCR (RT-PCR) and mRNA expression. PPMa: parasitic phase Miamiensis avidus; F: forward; R: reverse

\begin{tabular}{|c|c|c|c|c|}
\hline Target & Primers & Sequence & $\begin{array}{l}\text { Product } \\
\text { size (bp) }\end{array}$ & $\begin{array}{c}\text { PCR } \\
\text { cycles }\end{array}$ \\
\hline \multicolumn{5}{|l|}{ Clone } \\
\hline \multirow[t]{2}{*}{ РРМа-1 } & $1 \mathrm{~F}$ & 5'-AGT GAT ATG TGG AAT GAG GAA CAC ACA ATG-3' & 240 & 30 \\
\hline & $1 \mathrm{R}$ & 5'-TAT GAT GGA GAC TAA AGA GAT TAT ATG CAG-3' & & \\
\hline \multirow{2}{*}{ PPMa-5 } & $5 \mathrm{~F}$ & 5'-GAA AGA ACA CCG TTA TCA AGA AAG CTA TTG-3' & 134 & 23 \\
\hline & $5 \mathrm{R}$ & 5'-TCC ATA TAA AGA TTC TAA TTC GGG CAT AGG-3' & & \\
\hline \multirow[t]{2}{*}{ РPМа-6 } & $6 \mathrm{~F}$ & 5'-ACA TTA ATA CAA TTT AGA AAG ACT TAC C-3' & 167 & 30 \\
\hline & $6 \mathrm{R}$ & 5'-ATC CAT GTT TGA ATC CTT GTG ATC AAT ATC-3' & & \\
\hline \multirow[t]{2}{*}{ РРМа-8 } & $8 \mathrm{~F}$ & 5'-TTT ATA CAG TCT TAA ATC CAA GCA TTA CAC-3' & 121 & 30 \\
\hline & $8 \mathrm{R}$ & 5'-ATT GTC ATC AGG GTA ATA AGT GAA GAG AGG-3' & & \\
\hline \multirow{2}{*}{ РPМа-9 } & $9 \mathrm{~F}$ & 5'-TGG AGA AAG TTC AAG ATA AGT TAC AAA TG-3' & 383 & 30 \\
\hline & 9R & 5'-AGC TAT AAA TAT CAC CAG CCT GAG TAG G-3' & & \\
\hline \multirow{2}{*}{ PPMa-10 } & $10 \mathrm{~F}$ & 5'-AAA GAA TTA CTC TCG ATG AAG TAT TAG AAC-3' & 149 & 25 \\
\hline & 10R & 5'-AAA TTT GTT CCT TAT TGC TCA TTA TTC C-3' & & \\
\hline \multirow[t]{2}{*}{ PPMa-11 } & $11 \mathrm{~F}$ & 5'-CCT ACG AGG CTC AAC AAC TCA TAA GGT CTT G-3' & 222 & 29 \\
\hline & $11 \mathrm{R}$ & 5'-CGA ATT CTA GTT GTT GTT GTT GCT ATT CGA AG-3' & & \\
\hline \multirow[t]{2}{*}{ PPMa-15 } & $15 \mathrm{~F}$ & 5'-ATG CTC TCC TCT ATG CCT TAC TTG TTC TAC-3' & 239 & 25 \\
\hline & $15 \mathrm{R}$ & 5'-TTT ATG TAA CTC CTG GGT CAG TAT CTA TGC-3' & & \\
\hline \multirow[t]{2}{*}{ PPМа-19 } & $19 \mathrm{~F}$ & 5'-ATC CAA ATT CGT CAA TAA CAT TCC CAT TG-3' & 223 & 25 \\
\hline & $19 \mathrm{R}$ & 5'-GTG AAT AAT ACC CAA TCC TCC ACA TCT AGC-3' & & \\
\hline \multirow[t]{2}{*}{ РPМа-23 } & $23 \mathrm{~F}$ & 5'- ATT CGG AAC CAG ATA TGG AGC CGC TTT AAG-3' & 261 & 29 \\
\hline & $23 \mathrm{R}$ & 5'-TCG GCA TCG GCA GCA GCG GCG GCT TC-3' & & \\
\hline \multirow[t]{2}{*}{ PРМа-24 } & $24 \mathrm{~F}$ & 5'-TTG CAG AAG GGA TTA CCT ACA TAA GTG AAG-3' & 197 & 28 \\
\hline & $24 \mathrm{R}$ & 5'-TGC AAT AAC TAC AGA ACA TAC AAA GAA TCC-3' & & \\
\hline \multirow[t]{2}{*}{ PPMa-26 } & $26 \mathrm{~F}$ & 5'-CTG TTC GGA AGA ATG AAG GGT CTT ACA G-3' & 357 & 25 \\
\hline & $26 \mathrm{R}$ & 5'-TCC GAG ACA CTA GAA TTG TCC GTT AAT C-3' & & \\
\hline \multirow[t]{2}{*}{ PPMa-28 } & $28 \mathrm{~F}$ & 5'-AGC TCA GCT GCT AAG ACA AAG AGG TGT AGA GG-3' & 193 & 20 \\
\hline & $28 \mathrm{R}$ & 5'-CTA TAC TTT AGA CTC AGC AGC AGC TTT AGC C-3' & & \\
\hline \multirow[t]{2}{*}{ PРМа-29 } & $29 \mathrm{~F}$ & 5'-ATG ATC ATG CAA TGA CAT ATG GAT ATT CCA G-3' & 155 & 31 \\
\hline & $29 \mathrm{R}$ & 5'-TAT AAG CAT TAT TTT AGG ATC AAC AAC AGG AAC-3' & & \\
\hline \multirow[t]{2}{*}{ PPМа-37 } & $37 \mathrm{~F}$ & 5'-ACT AAT GGA AGA AGT ATA ATC GAT AGG GAG-3' & 233 & 32 \\
\hline & $37 \mathrm{R}$ & 5'-CAA TGA GTA GAG TCC ATG CAG CAA TAT GGC C-3' & & \\
\hline \multirow[t]{2}{*}{ PРМа-39 } & $39 \mathrm{~F}$ & 5'-CTT AAG CCG ATG CAC CTA ATG CTG CCA C-3' & 208 & 25 \\
\hline & $39 \mathrm{R}$ & 5'-TTG ACA TTT TCT GCG GCT CCC CCT TCA GC-3' & & \\
\hline \multirow{3}{*}{$\begin{array}{l}\text { Gene } \\
\beta \text {-tubulin }\end{array}$} & & & & \\
\hline & BTUF & 5'-GGA CCT TTC GGA CAA CTC TTC AG-3' & 684 & 28 \\
\hline & BTUR & 5'-TCT GGG ATC GGC GGC GCA CAT CAT G-3' & & \\
\hline
\end{tabular}


Verification of SSH results by semi-quantitative reverse transcription PCR (RT-PCR). To further verify differential expression of the isolated genes, semiquantitative RT-PCR was performed. Total RNAs were isolated from the ciliates from CHSE-culture and artificially infected flounder. cDNA was synthesized from $500 \mathrm{ng}$ of total RNA using Moloney murine leukemia virus (M-MLV) reverse transcriptase and Oligo $(\mathrm{dT})_{15}$ Primer (Promega) were used in RT-PCR. Primer pairs for randomly selected clones were designed from the sequences obtained by random sequencing of SSH clones (Table 1). PCR was performed using Takara r-Taq premix and $1 \mu \mathrm{l}$ of 10 -fold diluted cDNA in $20 \mu \mathrm{l}$ reaction. For normalization, the $\beta$-tubulin gene was used as the control. Thermal cycling conditions were 1 cycle of $3 \mathrm{~min}$ at $95^{\circ} \mathrm{C}$ (initial denaturation), followed by 28 cycles (for $\beta$-tubulin) or 20 to 32 cycles (for each $\mathrm{SSH}$ gene) of $30 \mathrm{~s}$ at $95^{\circ} \mathrm{C}, 30 \mathrm{~s}$ at $55^{\circ} \mathrm{C}, 30 \mathrm{~s}$ at $72^{\circ} \mathrm{C}$. The size of PCR products and optimal PCR cycles used in this study are shown in Table 1. Optimal PCR cycles of selected genes were determined after confirmation by agarose gel electrophoresis of PCR product taken at every 2 or 3 cycles from 15 to 33 cycles.

\section{RESULTS AND DISCUSSION}

To identify a putative set of genes involved in the parasitic phase of Miamiensis avidus, 510 individual clones were single run sequenced. The efficiency of the present subtraction was evaluated by PCR with a primer set specific for $\beta$-tubulin gene of M. avidus. As a result, PCR amplification of $\beta$-tubulin gene shows that it appeared after 18 cycles when using the unsubtracted tester cDNA as a template, but was not detected until after 28 cycles when using the subtracted cDNA as a template (Fig. 1). This result suggests that cDNA shared by both tester and driver was reduced efficiently.

Of the $510 \mathrm{SSH}$ clones, 21 clones of 6 putative genes did not show homology to any sequences in the public database, which suggested that they could be novel genes or represent the variable $5^{\prime}$ or $3^{\prime}$ untranslated region (UTR) of the genes (Table 2). The expectation values (E-values) of 117 clones encoding 9 putative genes were $>1 \times 10^{-5}$. The other 372 clones that met the criterion of $E$-value $<1 \times 10^{-5}$ were matched to 26 known sequences in the database, and among these clones, 73 clones of 5 putative genes showed homology to putative proteins derived from Tetrahymena thermophila nucleotide sequences. We have deposited the partial sequences of putative genes on the EST database of GenBank. Semi-quantitative RT-PCR of cDNA synthesized from both CHSE-cultured and parasiticphase Miamiensis avidus was performed to confirm

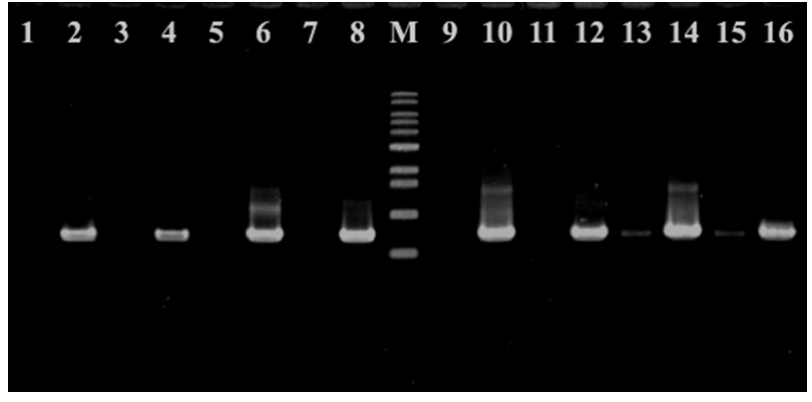

Fig. 1. Subtraction efficiency was evaluated by PCR using $\beta$ tubulin gene-specific primers of Miamiensis avidus. PCR was performed on the secondary-nested PCR products of the forward-subtracted cDNA (Lanes 1, 5, 9, 13), unsubtracted control cDNA for forward subtraction (Lanes $2,6,10,14)$, reversesubtracted cDNA (Lanes 3, 7, 11, 15), and unsubtracted control cDNA for reverse subtraction (Lanes 4, 8, 12, 16). A total of $5 \mu \mathrm{l}$ of PCR products were removed after 18 cycles (Lanes 1 to 4), 23 cycles (Lanes 5 to 8), 28 cycles (Lanes 9 to 12), and 33 cycles (Lanes 13 to 16) and electrophoresed on a $1 \%$ agarose gel. $\mathrm{M}$ : $1 \mathrm{~kb}$ DNA ladder (Bioneer)

differentially expressed genes in parasitic phase $M$. avidus. As shown in Fig. 2, the tested genes were differentially expressed in parasitic phase $M$. avidus, whereas the $\beta$-tubulin gene was evenly expressed in both cultured and parasitic phase ciliates.

Of the 372 clones $\left(E\right.$-value $\left.<1 \times 10^{5}\right)$, 106 clones showed homology to the acidic ribosomal P0 protein. The acidic ribosomal P0 protein is associated with the translocation step of protein synthesis, along with other ribosomal proteins P1/P2 (Liljas 1991). The conserved $\mathrm{C}$-terminal domain of the $\mathrm{P}$ proteins is very antigenic, and the protective or immunological role of antibodies to this domain has been reported in several pathogenic protozoans of mammals (Skeiky et al. 1994, Soto et al. 1995, Chatterjee et al. 2000a,b, Zhang et al. 2007). Furthermore, the surface expression of the P0 protein on apicomplexan patrasites, such as Plasmodium falciparum and Toxoplasma gondii, has been demonstrated (Chatterjee et al. 2000a,b, Singh et al. 2002). Although the antigenic potential of P0 protein in ciliates has not been reported, the present result suggests that the ribosomal P0 protein of Miamiensis avidus might be used as an antigen candidate for a subunit vaccine against scuticociliatosis.

In the present study, many of the differentially expressed clones corresponded to genes that are involved in cellular signaling such as delta 8-sphingolipid desaturase, inosine monophosphate dehydrogenases (IM$\mathrm{PDH}$ /guanosine monophosphate reductase (GMPR) domain-containing protein, protein kinase domain-containing protein, and epidermal growth factor (EGF)-like domain-containing protein. The putative delta 8-sphingolipid desaturase encoding clones were 


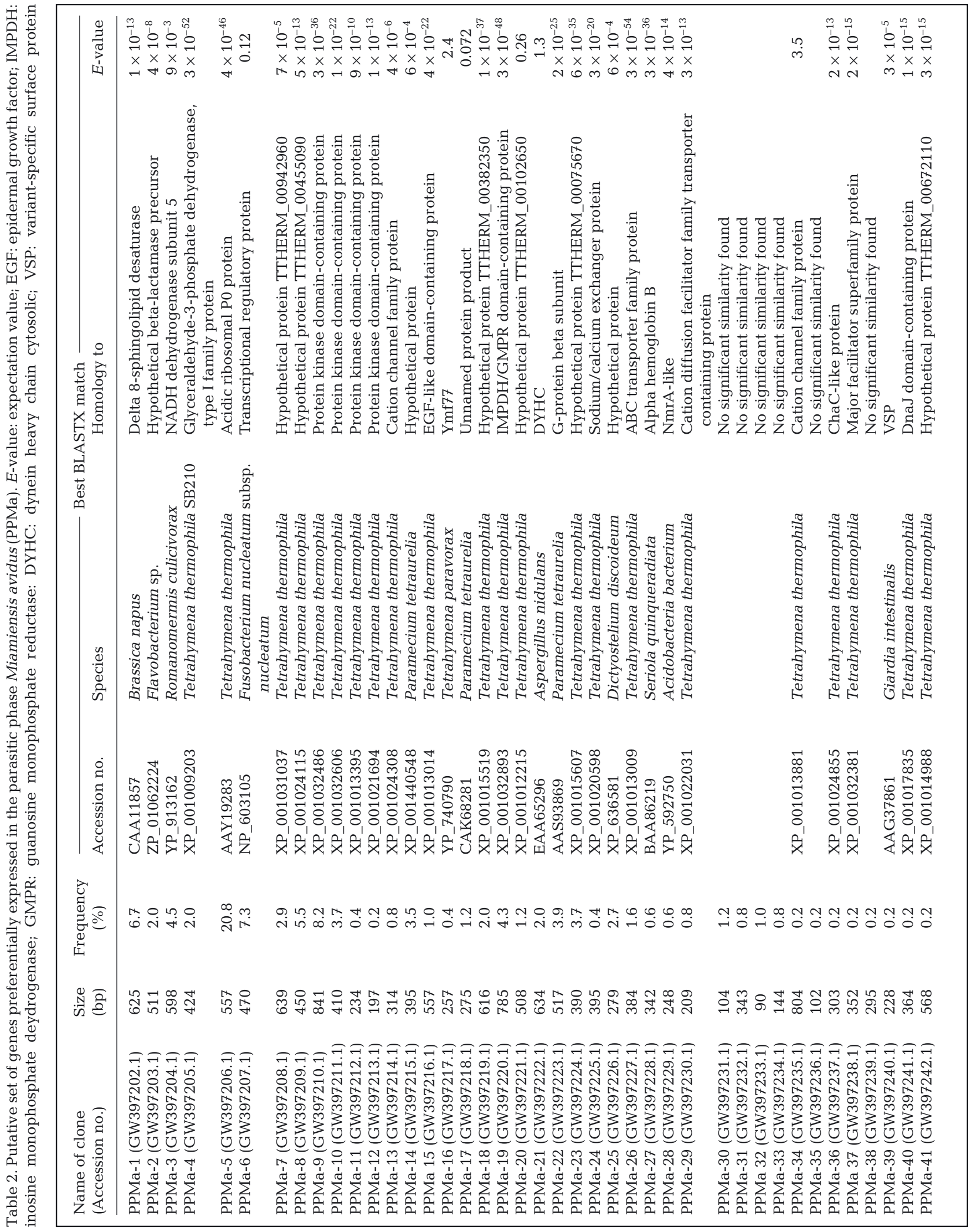




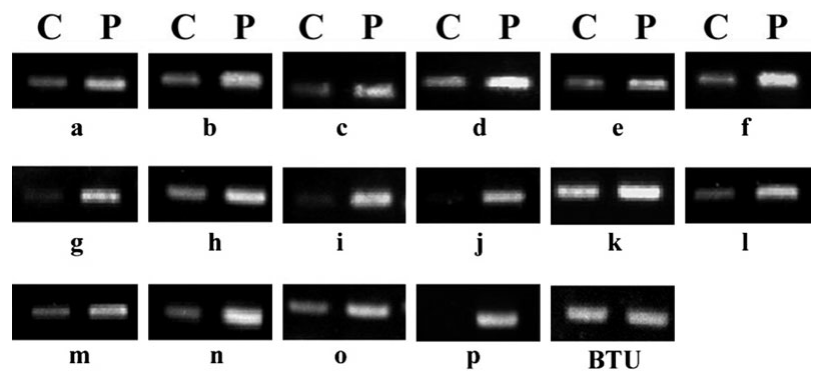

Fig. 2. Semi-quantitative reverse transcription-PCR analysis of differentially expressed genes in parasitic-phase Miamiensis avidus. cDNAs used as PCR templates were synthesized from total RNA of the Chinook salmon embryo (CHSE)cultured ciliates and the parasitic phase ciliates. C: CHSEcultured $M$. avidus; P: parasitic phase of $M$. avidus: (a) PPMa1, delta 8-sphingolipid desaturase; (b) PPMa-5, acidic ribosomal P0 protein; (c) PPMa-6, transcriptional regulatory protein; (d) PPMa-8, a hypothetical protein; (e-g) PPMa-9 to 11, protein kinase domain-containing protein; (h) PPMa-15, epidermal growth factor (EGF)-like domain-containing protein; (i) PPMa-19, inosine monophosphate dehydrogenases (IMPDH)/guanosine monophosphate reductase (GMPR) domain containing protein; (j) PPMa-23, hypothetical protein; (k) PPMa-24, sodium/calcium exchanger protein; (l) PPMa26, ABC transporter family protein; (m) PPMa-28, NmrA-like protein; (n) PPMa-29, cation diffusion facilitator family transporter-containing protein; (o) PPMa-37, major facilitator superfamily protein; (p) PPMa-39, variant-specific surface protein (VSP); BTU: $\beta$-tubulin gene used as an internal standard for normalization. PCR products were analyzed on $1.5 \%$ agarose gel stained with ethidium bromide

the second most abundant clones (34 clones). Sphingolipids are a family of membrane lipids in eukaryotic cells, and consist of a long-chain base (LCB) and a single amide-linked fatty acid (Futerman \& Hannun 2004). Sphingolipids and their catabolites are involved in regulating cellular processes, such as cell proliferation, differentiation, migration, apoptosis, and inflammation (Futerman \& Hannun 2004, Ogretmen \& Hannun 2004). Desaturation of sphingolipid LCB affects the subsequent activity of both the sphingolipid and its derivatives. The essential roles of sphingolipids in infectivity and virulence of a pathogenic protozoan parasite Leishmania have been demonstrated (Zhang et al. 2003, Denny et al. 2004). Thus, the role of delta 8-sphingolipid desaturase in infectivity and virulence of Miamiensis avidus should be further studied. The clones encoding putative IMPDH/GMPR domain-containing protein were the third most abundant clones (22 clones). IMPDH catalyzes the formation of XMP from IMP, a rate-limiting reaction of de novo GTP biosynthesis, and is associated with cell proliferation and neoplastic cell transformation (Markham et al. 1999), which makes it a target for anticancer, antiviral, antimicrobial, antiprotozoan therapies (Franchetti \& Grifantini 1999, Hedstrom 1999, Sullivan et al. 2005). GMPR catalyzes the reductive deamination of
GMP to IMP, and plays an important role in maintaining the intracellular balance of A and G nucleotides (Li et al. 2006). The clones encoding protein kinase domaincontaining protein were the fourth most abundant clones (21 clones). Many cellular processes including intercellular communication and coordination are controlled by protein phosphorylation, and protein kinases conduct almost all protein phosphorylation in eukaryotic cells (Livneh \& Fishman 1997). Protein kinases in many parasitic protozoans have been investigated as drug targets (Doerig et al. 2002, 2005) since protein kinases play important roles through phosphorylating other proteins involved in parasite invasion and survival (Ghosh et al. 2010, Leykauf et al. 2010). Five clones encoding the EGF-like domain-containing protein were isolated from the SSH library. EGF domains are involved in the modulation of cell growth and development through intercellular signaling, which is mediated by EGFcontaining ligands and receptors on the cell surface (Kansas et al. 1994). Recently, the EGF-like domaincontaining proteins have been identified as vaccine candidate antigens against blood stages of Plasmodium falciparum (Burns et al. 2000, Black et al. 2001).

Another group of molecules that we found to be expressed preferentially in the parasitic phase ciliates is related to transporting molecules, such as ABC transporter family protein (8 clones), cation diffusion facilitator family transporter-containing protein (4 clones), and major facilitator superfamily protein (1 clone). In addition, 3 clones of NmrA-like protein, which negatively regulates transcription and is involved in the controlling of nitrogen metabolite repression in fungi, were isolated (Stammers et al. 2001).

Surface proteins of parasites are considered as ideal vaccine candidates because surface-exposed proteins can elicit production of antibodies, which can act as opsonins and/or inhibit colonization and invasion of parasites (Leid et al. 1987, Kedzierski et al. 2004, Mello et al. 2004, Fankhauser et al. 2007). In mammalian protozoan parasites belonging to genus Plasmodium, Trypanosoma, and Leishmania, many vaccination attempts revealed that protective immunity was obtained by immunization with recombinant surface antigen (Musoke et al. 1992, Mello et al. 2004) or plasmid DNA encoding surface antigen (Nielsen et al. 1999, Dumonteil et al. 2004). In the present study, only one clone was matched to a surface protein (acidic ribosomal PO protein), a variant-specific surface protein.

In conclusion, the data reported here identify for the first time a set of genes differentially expressed in the parasitic phase Miamiensis avidus. These genes should be further studied to know how the ciliates survive and proliferate in the host fish, and this could provide new strategies for anti-scuticociliates vaccine. 
Acknowledgements. This study was supported by the research fund (project no. 20088033-1) from the Ministry of Land, Transport and Maritime Affairs, Republic of Korea, and supported by Pukyong National University in the 2009 postdoc program.

\section{LITERATURE CITED}

Black CG, Wu T, Wang L, Hibbs AR, Coppel RL (2001) Merozoite surface protein 8 of Plasmodium falciparum contains two epidermal growth factor-like domains. Mol Biochem Parasitol 114:217-226

- Burns JM Jr, Belk CC, Dunn PD (2000) A protective glycosylphosphatidylinositol-anchored membrane protein of Plasmodium yoelii trophozoites and merozoites contains two epidermal growth factor-like domains. Infect Immun 68:6189-6195

Caron F, Meyer E (1989) Molecular basis of surface antigen variation in Paramecia. Annu Rev Microbiol 43:23-42

> Chatterjee S, Singh S, Sohoni R, Kattige V and others (2000a) Characterization of domains of the phosphoriboprotein P0 of Plasmodium falciparum. Mol Biochem Parasitol 107: $143-154$

> Chatterjee S, Singh S, Sohoni R, Singh NJ, Vaidya A, Long C, Sharma S (2000b) Antibodies against ribosomal phosphoprotein $\mathrm{P0}$ of Plasmodium falciparum protect mice against challenge with Plasmodium yoelii. Infect Immun 68: 4312-4318

> Clark TG, Lin T, Dickerson HW (1995) Surface immobilization antigens of Ichthyophthirius multifiliis: their role in protective immunity. Annu Rev Fish Dis 5:113-132

> Denny PW, Goulding D, Ferguson MA, Smith DF (2004) Sphingolipid-free Leishmania are defective in membrane trafficking, differentiation and infectivity. Mol Microbiol 52:313-327

> Dickerson HW, Clark TG (1996) Immune response of fishes to ciliates. Annu Rev Fish Dis 6:107-120

> Dickerson HW, Clark TG (1998) Ichthyophthirius multifiliis: a model of cutaneous infection and immunity in fishes. Immunol Rev 166:377-384

Dickerson HW, Clark TG, Leff AA (1993) Serotypic variation among isolates of Ichthyophthirius multifiliis based on immobilization. J Eukaryot Microbiol 40:816-820

> Doerig C, Meijer L, Mottram JC (2002) Protein kinases as drug targets in parasitic protozoa. Trends Parasitol 18: 366-371

> Doerig C, Billker O, Pratt D, Endicott J (2005) Protein kinases as targets for antimalarial intervention: kinomics, structure-based design, transmission-blockade, and targeting host cell enzymes. Biochim Biophys Acta 1754:132-150

> Dumonteil E, Escobedo-Ortegon J, Reyes-Rodriguez N, Arjona-Torres A, Ramirez-Sierra MJ (2004) Immunotherapy of Trypanosoma cruzi infection with DNA vaccines in mice. Infect Immun 72:46-53

Fankhauser N, Nguyen-Ha TM, Adler J, Mäser P (2007) Surface antigens and potential virulence factors from parasites detected by comparative genomics of perfect amino acid repeats. Proteome Sci 5:20

Franchetti P, Grifantini M (1999) Nucleoside and non-nucleoside IMP dehydrogenase inhibitors as antitumor and antiviral agents. Curr Med Chem 6:599-614

Futerman AH, Hannun YA (2004) The complex life of simple sphingolipids. EMBO Rep 5:777-782

Ghosh AS, Ray D, Dutta S, Raha S (2010) EhMAPK, the mitogen-activated protein kinase from Entamoeba histolytica is associated with cell survival. PLoS One 5(10):e13291
Hedstrom L (1999) IMP dehydrogenase: mechanism of action and inhibition. Curr Med Chem 6:545-560

Iglesias R, Paramá A, Álvarez MF, Leiro J, Ubeira FM, Sanmartín ML (2003) Philasterides dicentrarchi (Ciliophora: Scuticociliatida) expresses surface immobilization antigens that probably induce protective immune responses in turbot. Parasitology 126:125-134

Jung SJ, Kitamura SI, Song JY, Oh MJ (2007) Miamiensis avidus (Ciliophora: Scuticociliatida) causes systemic infection of olive flounder Paralichthys olivaceus and is a senior synonym of Philasterides dicentrarchi. Dis Aquat Org 73: $227-234$

> Kansas G, Saunders K, Ley K, Zakrzewicz A and others (1994) A role for the epidermal growth factor-like domain of Pselectin in ligand recognition and cell adhesion. J Cell Biol 124:609-618

Kedzierski L, Montgomery J, Bullen D, Curtis J, Gardiner E, Jimenez-Ruiz A, Handman E (2004) A leucine-rich repeat motif of Leishmania parasite surface antigen 2 binds to macrophages through the complement receptor 3. J Immunol 172:4902-4906

Kim SM, Cho JB, Kim SK, Nam YK, Kim KH (2004) Occurrence of scuticociliatosis in olive flounder Paralichthys olivaceus by Philasterides dicentrarchi (Ciliophora: Scuticociitida). Dis Aquat Org 62:233-238

Lee EH, Kim KH (2008) Can the surface immobilization antigens of Philasterides dicentrarchi (Ciliophora: Scuticociliatida) be used as target antigens to develop vaccines in cultured fish? Fish Shellfish Immunol 24:142-146

Leid RW, Suquet CM, Tanigoshi L (1987) Parasite defense mechanisms for evasion of host attack: a review. Vet Parasitol 25:147-162

Leykauf K, Treeck M, Gilson PR, Nebl T and others (2010) Protein kinase a dependent phosphorylation of apical membrane antigen 1 plays an important role in erythrocyte invasion by the malaria parasite. PLoS Pathog 6: e1000941

> Li J, Wei Z, Zheng M, Gu X and others (2006) Crystal structure of human guanosine monophosphate reductase 2 (GMPR2) in complex with GMP. J Mol Biol 355:980-988

- Liljas A (1991) Comparative biochemistry and biophysics of ribosomal proteins. Int Rev Cytol 124:103-136

> Livneh E, Fishman DD (1997) Linking protein kinase C to cellcycle control. Eur J Biochem 248:1-9

> Markham GD, Bock CL, Schalk-Hihi C (1999) Acid-base catalysis in the chemical mechanism of inosine monophosphate dehydrogenase. Biochemistry 38:4433-4440

Mello K, Daly TM, Long CA, Burns JM, Bergman LW (2004) Members of the merozoite surface antigen 7 family with similar expression patterns differ in ability to protect against Plasmodium yoelii malaria. Infect Immun 72 : 1010-1018

Musoke A, Morzaria S, Nkonge C, Jones E, Nene V (1992) A recombinant sporozoite surface antigen of Theileria parva induces protection in cattle. Proc Natl Acad Sci USA 89: $514-518$

> Nielsen HV, Lauemoller SL, Christiansen L, Buus S, Fomsgaard A, Petersen E (1999) Complete protection against lethal Toxoplasma gondii infection in mice immunized with a plasmid encoding the SAG1 gene. Infect Immun 67:6358-6363

> Ogretmen B, Hannun YA (2004) Biologically active sphingolipids in cancer pathogenesis and treatment. Nat Rev Cancer 4:604-616

Simon MC, Schmidt HJ (2007) Antigenic variation in ciliates: antigen structure, function, expression. J Eukaryot Microbiol 54:1-7 
Singh S, Sehgal A, Waghmare S, Chakraborty T, Goswami A, Sharma S (2002) Surface expression of the conserved ribosomal protein P0 on parasite and other cells. Mol Biochem Parasitol 119:121-124

Skeiky YAW, Benson DR, Elwasila M, Badaro R, Burns JM Jr, Reed SG (1994) Antigens shared by Leishmania species and Trypanosoma cruzi: immunological comparison of the acidic ribosomal P0 proteins. Infect Immun 62:1643-1651

Song JY, Kitamura SI, Oh MJ, Kang HS, Lee JH, Tanaka SJ, Jung SJ (2009) Pathogenicity of Miamiensis avidus (syn. Philasterides dicentrarchi), Pseudocohnilembus persalinus, Pseudocohnilembus hargisi and Uronema marinum (Ciliophora, Scuticociliatida). Dis Aquat Org 83:133-143

Soto M, Requena JM, Quijada L, Guzman F, Patarroyo ME, Alonso C (1995) Identification of the Leishmania infantum P0 ribosomal protein epitope in canine visceral leishmaniasis. Immunol Lett 48:23-28

Stammers DK, Ren J, Leslie K, Nichols CE and others (2001) The structure of the negative transcriptional regulator NmrA reveals a structural superfamily which includes the short-chain dehydrogenase/reductases. EMBO J 20: 6619-6626

Editorial responsibility: Catherine Collins, Aberdeen, UK
Sullivan WJ Jr, Dixon SE, Li C, Striepen B, Queener SF (2005) IMP dehydrogenase from the protozoan parasite Toxoplasma gondii. Antimicrob Agents Chemother 49: 2172-2179

Wang X, Dickerson HW (2002) Surface immobilization antigen of the parasitic ciliate Ichthyophthirius multifiliis elicits protective immunity in channel catfish (Ictalurus punctatus). Clin Diagn Lab Immunol 9:176-181

> Wang X, Clark TG, Noe J, Dickerson HW (2002) Immunisation of channel catfish, Ictalurus punctatus, with Ichthyophthirius multifiliis immobilisation antigens elicits serotype-specific protection. Fish Shellfish Immunol 13: $337-350$

Zhang K, Showalter M, Revollo J, Hsu FF, Turk J, Beverley SM (2003) Sphingolipids are essential for differentiation but not growth in Leishmania. EMBO J 22: 6016-6026

Zhang H, Lee EG, Liao M, Compaore MK and others (2007) Identification of ribosomal phosphoprotein P0 of Neospora caninum as a potential common vaccine candidate for the control of both neosporosis and toxoplasmosis. Mol Biochem Parasitol 153:141-148

Submitted: July 2, 2010; Accepted: December 10, 2010

Proofs received from author(s): March 9, 2011 